\title{
Lean Manufacturing Effects in a Serbian Confectionery Company - Case Study
}

\author{
Ilija Djekic', Dragan Zivanovic ${ }^{2}$, Sladjana Dragojlovic'2, Radoslava Dragovic ${ }^{2}$
}
${ }^{1}$ University of Belgrade, Faculty of Agriculture, Department of Food Safety and Quality Management, Nemanjina 6, 11080 Belgrade, Serbia, idjekic@agrif.bg.ac.rs (corresponding author)
2 Koncern Bambi-Banat ad, 11070 Novi Beograd, Serbia

\begin{abstract}
Background and Purpose: The objective of this paper was to evaluate effects of implementing lean manufacturing in a Serbian confectionery production company during a period of 24 months, emphasizing observed benefits and constrains. Company 'case study' is a leading confectionery producer in Serbia with annual production of more than $25,000 \mathrm{t}$.

Methodology/Approach: The research method was case study. The approach in implementing lean manufacturing was structured in five phases, as follows: (i) training, (ii) analysis of lean wastes on one technological line, (iii) choice of lean tools to be implemented in the factory, (iv) implementation of lean tools in production and maintenance, (v) development of continual improvement sector and further deployment of lean tools.

Results: Lean manufacturing tools implemented in the production process were visual control and single minute exchange of dies (SMED). Maintenance process implemented 5S with total productive maintenance (TPM) and problem solving sessions being the tools implemented in both processes. During the observed period, results of these tools showed the following: visual control tables initiated 61 improvement memos out of which $39 \%$ were fully implemented; a total of 2284 minor problems had been recorded, with over $95 \%$ of issues revealed in due time; total SMED time decreased for $7.6 \%$; 19 problem solving sessions were initiated with $58 \%$ of solving effectiveness, and the remaining converted to on-going projects. In maintenance $5 \mathrm{~S}$ improved from 29.9 to 60.3; overall equipment effectiveness (OEE) indicator increased from $87.9 \%$ to $92.3 \%$; mean time between failure (MTBF) increased for $16.4 \%$.

Conclusion: As a result of all activities, 20 in-house trainings and 2 'kaizen' events including motivational training have been initiated with 54 documents being revised and improved in order to contribute to more efficient processes.
\end{abstract}

Keywords: Lean manufacturing; confectionery production; benefits; constraints

\section{Introduction}

The birth of lean was in Japan within Toyota in the 1940s and was developed with its suppliers in the 1950s and 1960s as the Toyota Production System (TPS) (Ohno 1998; Schonberger, 2007). The basic idea in TPS is to produce the kind of products needed, at the time needed and in the quantities needed such that unnecessary intermediate and finished product inventories can be eliminated (Monden, 1983). It is based around the desire to produce in a continuous flow which did not rely on long production runs to be efficient (Melton, 2005).
Lean tools and techniques within the 'lean manufacturing' concept include: (a) Streamlined layout - a layout designed according to optimum operational sequence; (b) Standard work - consistent performance of a task according to defined methods with no waste; (c) Visual control - a visual method of measuring performance at the 'shop floor; use of this technique enables a fast check of all information - tooling, parts, production activities and process indicators at a glance; (d) 5 S's (sort, set in order, shine, standardize, sustain) - five activities used to create a workplace suited for visual control and lean practices; (e) Point-Of-Use-Storage (POUS) - raw materials, parts, information, tooling, work

Received: September $6^{\text {th }}, 2013$; revised: $10^{\text {th }}$ June 2014; accepted; July $18^{\text {th }}, 2014$ 
standards, supplies and procedures are stored where needed; (f) Batch size reduction is a technique in reducing batches to the smallest possible size to enable single and continuous flow; (g) SMED (single minute exchange of dies) - a changeover reduction technique defined as a time between the last good piece of the current run and the first good piece of the next run; (h) Poke yoke - an 'error-proofing' technique - a process used to prevent errors from occurring or to immediately point out a defect as it occurs; (i) Selfinspection - inspection and process control by competent employees so they understand if the product passed to next operation is of acceptable quality; (j) 'Jidoka' or 'autonomous machine' - form of automation in which equipment automatically inspects each item after producing it, ceases production and notifies humans if a defect is detected; (k) Total productive maintenance (TPM) which covers practices primarily designed to maximize equipment effectiveness through planned predictive and preventive maintenance of the equipment and use of maintenance optimization techniques; (l) Just-in-time (JIT) philosophy related to 'zero inventories' or 'stockless' production so batches should always be as small as possible, in order to achieve onepiece flow with batches sizes of one so "only the necessary products, at the necessary time, in the necessary quantity are delivered"; (m) Cellular and flow - physically linking and arranging manual and machine process steps into the most efficient combination; (n) Kanban - a visual signal to support flow by 'pulling' product through the manufacturing process as required by the internal / external customer; (o) Value stream mapping (VSM) a method of mapping current and future value flow of the entire production process (Alukal and Manos, 2006; Holweg, 2007; Melton, 2005; Rooney and Rooney, 2005; Rubio and Corominas, 2008; Shah and Ward, 2003, 2007)

The objective of this paper was to evaluate effects of implementing lean manufacturing in a Serbian confectionery production company during a period of 24 months, emphasizing observed benefits and constrains.

\subsection{Effect of lean manufacturing in food industry}

Effects of implemented various quality improvement concepts have been analyzed by various authors focusing their research on different segments (Table 1). Depending on the timing of evaluation of effects, three different kinds of evaluations can be recognized: ex ante (prior to implementing an improvement concept), ongoing/mid-term (during implementation) and ex post (upon implementation).

Lean manufacturing has its advantages in the fact that it's a concept that was developed more than 50 years ago and has been theoretically analyzed by many authors. In order to evaluate these effects, the ex post approach is used through structured surveys with the possibility to enumerate the inputs and outcomes, but with certain difficulties in estimating the overall benefits and constraints. Limited studies from the field, time consuming approach, small sample size and a few studies from the food industry raise doubts about the relevance of results and challenge this approach.

\section{Materials and method}

A structured survey was conducted from January until March 2013. The data used for this research were collected, processed and analyzed for a period of 24 months (20112012). The continual improvement manager of the company was asked to provide the authors with their QMS documents and record. Review of documentation covered overview of production, maintenance, control and training records including records of non-conforming products, list of corrective and preventive actions and management review, including various monthly reports. Structure survey included on-site visits to the company and meetings, including e-mail and phone communication during the survey period. Data were processed using CMicrosoft Office Pack 2007.

Table 1: Effects of implemented quality improvement concepts according to recent studies

\begin{tabular}{|l|l|}
\hline Topic covered & Authors \\
\hline Quality management performance and effects & $\begin{array}{l}\text { (Arauz and Suzuki, 2004; Lagrosen and Lagrosen, 2005; Van } \\
\text { Der Spiegel, Luning, De Boer, Ziggers, and Jongen, 2006; } \\
\text { van der Spiegel, Luning, Ziggers, and Jongen, 2003) }\end{array}$ \\
\hline Use of quality tools in quality management & $\begin{array}{l}\text { (Alsaleh, 2007; Sousa, Aspinwall, Sampaio, and Rodrigues, } \\
\text { 2005) }\end{array}$ \\
\hline Total quality management practices & $\begin{array}{l}\text { (Beheshti and Lollar, 2003; Fotopoulos, Psomas, and Vouzas, } \\
\text { 2010; Psomas and Fotopoulos, 2010) }\end{array}$ \\
\hline Lean manufacturing & $\begin{array}{l}\text { (Cagliano, Caniato, and Spina; Eroglu and Hofer, 2011; } \\
\text { Losonci, Demeter, and Jenei, 2011; Panizzolo, 1998; Shah } \\
\text { and Ward, 2003) }\end{array}$ \\
\hline
\end{tabular}




\subsection{Calculating and evaluating the results}

In order to present results, calculation of various indicators is further explained. Overall equipment efficiency as an indicator of total productive maintenance (TPM) was calculated by using the equation (1.1) (Chan, Lau, Ip, Chan, and Kong, 2005; Feld, 2001; Smith and Hawkins, 2004).

OEE $=$ Equipment Availability $\times$ Performance Efficiency $\times$ Quality Rate [\%]

Evaluating time saving in product changeovers, SMED index has been calculated according to the equation (1.2).

$S M E D=\frac{\text { Dplanned changeover time }- \text { Eachieved changeover time }}{\text { Eachieved changeover time }} \cdot 100[\%]$

Mean time between failure (MTBF) presents a statistical estimate of the time a component, subassembly, or operating unit will operate before failure will occur (Higgins and Wikoff, 2008). Calculation of this indicator is expressed in equation 1.3.

$M T B F=\frac{\text { (Operational time })-(\text { failure time })}{\text { number of failures }}[h]$

\subsection{Company 'case study'}

Company 'case study' was established 45 years ago and has developed from a small plant in Požarevac (Republic of Serbia), which initially employed 37 people and produced 167 tons of confectionary products annually, to what it is today - market leading company with factories in two cities - Požarevac (two production plants "I" and "II") and Vršac and annual average production of over 25,000 tones. Basic production portfolio covers 177 different products / stock keeping units (SKUs) produced on 16 production lines. On the 4th Brand Fair held in Belgrade in 2008, company's biscuit was promoted for "the most loved domestic brand" in all categories. In 2009, company was promoted as the company with products of the best quality. In May 2010, they received traditional annual reward of Belgrade Chamber of Commerce "Belgrade winner" for exceptional professional results in 2009. In the same year they received a 'Halal' certificate $^{1}$ for over 80 company products enabling export and trade with Muslim countries.

The company implemented and certified its quality management system according to ISO 9001 in 1997. Food safety system based on hazard analysis and critical control points (HACCP) was certified in 2002 being upgraded in 2011 by certifying their food safety management system according to ISO 22000 and FSSC 22000. In year 2004 they certified their environmental management system (EMS) according to ISO 14001 and in 2011 their occupational, health and safety management system according to BS OHSAS 18001.

In the mid of 2010, company decided to implement lean manufacturing in the company with the aim of improving effectiveness and efficiency focusing on production and maintenance. Period of implementation was November 2010 - December 2012 and the approach in implementing lean manufacturing was structured in five phases: (i) training, (ii) analysis of lean wastes on one technological line, (iii) choice of lean tools to be implemented in the factory, (iv) implementation of lean tools on chosen production lines in production and maintenance, (v) development of continual improvement sector and further deployment of lean tools throughout the entire factory.

\section{Results}

\subsection{Initial training}

First activity in implementing lean manufacturing was to conduct awareness training to middle management responsible for production, maintenance, control and purchasing processes. It included managers, shift leaders, supervisors, engineers and technologists. A total of 82 employees attended five one-day trainings during November and December 2010. The training covered introduction to the following lean tools referred to as building block of lean (G. and A., 2006): streamlined layout, standard work, visual controls, 5S, POUS, batch size reduction, SMED, poka-yoke, selfinspection, autonomation, TPM, JIT, cellular and flow, pull system / kanban. Value stream mapping has not been covered during the initial training. During the training, all participants were asked to evaluate possibility of implementing certain tools within their process in order to help the management in developing lean manufacturing. First option gave the respondents the opportunity to rate their degree of agreement with statement concerning usage of tools in the company according to a five-point Likert scale. The usage of tools was rated from 1 'not applicable in the company' to 5 'very applicable in the company', where 2 was referred to 'hardly applicable', 3 to 'possible to use' and 4 to 'applicable' (Table 2).

\subsection{Analysis of wastes on one technological line}

Waste of resources has a direct impact on costs and quality. Conversely, the elimination of wastes results in higher qual-

1 Halal foods are foods that Muslims are allowed to eat under Islamic dietary guidelines 
Table 2: Use of lean tools in the company

\begin{tabular}{|c|c|c|c|c|c|c|c|c|}
\hline Lean tools & $\begin{array}{l}\operatorname{Mean}^{1} \\
(\mathrm{n}=82)\end{array}$ & $\mathbf{S d}^{2}$ & $\begin{array}{c}\text { No answer } \\
{[\%]^{3}}\end{array}$ & $\begin{array}{c}\text { Rank 1 } \\
{[\%]^{3}}\end{array}$ & $\begin{array}{c}\text { Rank 2 } \\
{[\%]^{3}}\end{array}$ & $\begin{array}{c}\text { Rank 3 } \\
{[\%]^{3}}\end{array}$ & $\begin{array}{c}\text { Rank } 4 \\
{[\%]^{3}}\end{array}$ & $\begin{array}{c}\text { Rank } 5 \\
{[\%]^{3}}\end{array}$ \\
\hline $5 \mathrm{~S}$ & 4.7 & 0.5 & $2.4 \%$ & $0.0 \%$ & $0.0 \%$ & $3.7 \%$ & $20.7 \%$ & $73.2 \%$ \\
\hline Visual control & 4.6 & 0.7 & $3.7 \%$ & $0.0 \%$ & $0.0 \%$ & $8.5 \%$ & $24.4 \%$ & $63.4 \%$ \\
\hline Standard work & 4.3 & 0.9 & $2.4 \%$ & $1.2 \%$ & $4.9 \%$ & $8.5 \%$ & $29.3 \%$ & $53.7 \%$ \\
\hline Poka Yoke & 4.3 & 0.8 & $4.9 \%$ & $0.0 \%$ & $3.7 \%$ & $9.8 \%$ & $36.6 \%$ & $45.1 \%$ \\
\hline Streamlined layout & 4.2 & 0.9 & $3.7 \%$ & $1.2 \%$ & $2.4 \%$ & $13.4 \%$ & $34.1 \%$ & $45.1 \%$ \\
\hline TPM & 4.1 & 0.8 & $6.1 \%$ & $0.0 \%$ & $4.9 \%$ & $13.4 \%$ & $41.5 \%$ & $34.1 \%$ \\
\hline Self-inspection & 4.1 & 1.0 & $7.3 \%$ & $1.2 \%$ & $7.3 \%$ & $14.6 \%$ & $30.5 \%$ & $39.0 \%$ \\
\hline POUS & 4.0 & 0.8 & $3.7 \%$ & $0.0 \%$ & $1.2 \%$ & $24.4 \%$ & $40.2 \%$ & $30.5 \%$ \\
\hline SMED & 3.8 & 0.8 & $6.1 \%$ & $0.0 \%$ & $6.1 \%$ & $23.2 \%$ & $43.9 \%$ & $20.7 \%$ \\
\hline JIT & 3.8 & 1.1 & $4.9 \%$ & $4.9 \%$ & $6.1 \%$ & $20.7 \%$ & $32.9 \%$ & $30.5 \%$ \\
\hline Batch size reduction & 3.8 & 0.8 & $4.9 \%$ & $0.0 \%$ & $6.1 \%$ & $24.4 \%$ & $46.3 \%$ & $18.3 \%$ \\
\hline Autonomation & 3.5 & 0.9 & $6.1 \%$ & $3.7 \%$ & $6.1 \%$ & $35.4 \%$ & $36.6 \%$ & $12.2 \%$ \\
\hline Kanban & 3.0 & 1.1 & $9.8 \%$ & $9.8 \%$ & $20.7 \%$ & $30.5 \%$ & $22.0 \%$ & $7.3 \%$ \\
\hline Cellular and flow & 2.5 & 1.1 & $4.9 \%$ & $23.2 \%$ & $20.7 \%$ & $30.5 \%$ & $20.7 \%$ & $0.0 \%$ \\
\hline
\end{tabular}

$11=$ 'not applicable in the company', 2 = 'hardly applicable', $3=$ 'possible to use' $4=$ 'applicable', $5=$ 'very applicable in the company'

$2 \mathrm{Sd}$ - standard deviation

$3100 \%$ corresponds to $n=82$ respondents

ity, customer satisfaction, profitability, effectiveness and efficiency, (Alucal and Manos, 2006).

Due to the overall complexity of the company with many technological lines and diversity of product portfolio, it has been decided to evaluate lean 'wastes' on technological line "No. 9" where five different products are manufactured and changeovers are interesting due to the fact that for some changeovers, detailed cleaning and sanitation should be performed in order to avoid allergen cross contamination. The line works in three shifts, seven days a week. Evaluation of wastes was performed by observing the production process for four days in a row during the first month of the project (January 2011). Three methods were used: (i) interviewing workers on the line, (ii) reviewing available documents and records and (iii) taking photos and videos of most significant wastes.

First observation was connected to identifying the most predominant waste. Any activity in a process which does not add value to the customer is called 'waste', (Alukal and Manos, 2006; Melton, 2005). Eight types of waste have been evaluated, as follows: (i) defects, (ii) overproduction, (iii) waiting, (iv) non value added processing, (v) transportation, (vi) Inventory, (vii) motion of workpower and (viii) employee knowledge (Rooney and Rooney, 2005). Inventory was identified as the most significant confirming Ohno's conclusion that "the greatest waste of all is excess inventory" (Ohno, 1998).

Deeper analysis of wastes connected with time showed that SMED results have the greatest variations in both directions above and below targeted time. Records showed rounded figures on 5 minutes with low level of employee awareness on the importance of precise recording SMED results. Also, for some combinations of changeovers, there were no targeted times. Estimation of time savings for decreasing targeted values for one minute every two months for long changeovers (over 45 minutes) and one minute quarterly for shorter changeovers would achieve saving between $6,6 \%$ and $10 \%$. However, the primary task was to define target values.

In the same analysis, deployments of losses connected with OEE were transfers to six TPM losses, as follows: failures and set-up adjustments (connected with availability), reduced speed and minor stoppages (connected with performance) and production defects, start-up rejects and yield (connected with quality rate), (Higgins and Wikoff, 2008; Smith and Hawkins, 2004). Analysis showed the distribution of the losses with set-up and failures being the predominant with $66.4 \%$ of total lost time, followed by defects participating with $19.9 \%$ and reduced speed and minor stoppage contributing with $13.7 \%$.

\subsection{Choice of lean tools to be implemented in the factory}

Upon completion of training and analysis of wastes on one technological line, a 'Kaizen' event has been organized in order to present the results and inform employees which 
tools are to be implemented. In order to accept employees' choice of tools, management accepted their choice of $5 \mathrm{~S}$ and visual control (Table 2). On the other side, in line with the results from the analysis of waste where time has been identified as the major improvement resource, TPM and SMED have been chosen by the management. Finally, problems solving session have been initiated by employees from quality control.

Lean manufacturing tools implemented in the production process were visual control and single minute exchange of dies (SMED). Maintenance process implemented $5 \mathrm{~S}$ with total productive maintenance (TPM) and problem solving sessions being the tools implemented in both processes.

\section{Discussion}

\subsection{Visual control tables}

First visual control table has been posted on line "11", in the third month of the observed period. It has been decided to use control tables and record all problems that occurred during the week. Upon successful experience, two types of tables were designed - for communicating problems and for communicating performance indicators with improvement memos. In the next four months a total of 30 visual control tables have been placed within the production plant "I": two for the overall production, 11 next to production lines, 13 next to packaging system, three in raw materials preparation area and two in maintenance. A problem table consisted of the following data (date, shift, problem, solution, responsible person, due date, status and duration of downtime). Overall production performance indicators were number of quality and food safety complaints, product quality index and the number of injuries. Next to production and packaging lines indicators were Overall Equipment Effectiveness (OEE) index, product quality indicators and parameters from control charts. Production plant "II" started with the project in the $9^{\text {th }}$ month and until the end of the first year a total of six tables have been placed for the overall production, for production lines and for packaging systems.

During the observed period visual control tables initiated 61 improvement memos out of which $39 \%$ were fully implemented and a total of 2284 minor problems had been recorded, with over $95 \%$ of issues revealed in due time.

\subsection{Overall Equipment Effectiveness}

One of the fundamental measures used in TPM is OEE. World-class levels of OEE start at $85 \%$, targeting equipment availability at $90 \%$, performance efficiency at $95 \%$ and quality rate at $99 \%$ (Smith and Hawkins, 2004). The OEE index has been followed on nine production lines for the period of two years and it increased from $87.9 \%$ to $92.3 \%$ (Table 3).

During the first quarter of 2012 more precise method of recording data has been established so a certain dropdown effect occurred. Figure 1 gives an overview of the three indicators used for calculating OEE during the 24 month period.

\subsection{SMED}

In line with visual tables, within the production area "I", 24 SMED tables have been posted in order to follow the time for changeovers. In the first twelve months, time for changeovers have been recorded and followed on a shift basis in order to determine necessary time for all product combina-

Table 3: OEE on production lines during the observed period

\begin{tabular}{lcccccccc}
\hline & \multicolumn{1}{c}{ OEE } \\
& Q1 / 2011 & Q2 / 2011 & Q3 / 2011 & Q4 / 2011 & Q1 / 2012 & Q2 / 2012 & Q3 / 2012 & Q4 / 2012 \\
\hline Production line 1 & $85.2 \%$ & $87.9 \%$ & $83.2 \%$ & $81.6 \%$ & $82.5 \%$ & $83.6 \%$ & $89.7 \%$ & $91.1 \%$ \\
Production line 2 & $90.4 \%$ & $86.8 \%$ & $82.7 \%$ & $88.8 \%$ & $86.4 \%$ & $92.3 \%$ & $92.6 \%$ & $93.6 \%$ \\
Production line 3 & $89.9 \%$ & $81.1 \%$ & $84.9 \%$ & $72.1 \%$ & $58.0 \%$ & $75.2 \%$ & $83.6 \%$ & $85.6 \%$ \\
Production line 4 & $87.9 \%$ & $85.6 \%$ & $78.4 \%$ & $75.2 \%$ & $68.7 \%$ & $76.6 \%$ & $77.5 \%$ & $86.1 \%$ \\
Production line 5 & $87.6 \%$ & $84.2 \%$ & $80.8 \%$ & $86.1 \%$ & $80.5 \%$ & $81.7 \%$ & $87.7 \%$ & $95.3 \%$ \\
Production line 6 & $90.2 \%$ & $90.6 \%$ & $87.5 \%$ & $85.8 \%$ & $83.7 \%$ & $89.9 \%$ & $90.7 \%$ & $96.1 \%$ \\
Production line 7 & $85.1 \%$ & $86.6 \%$ & $85.1 \%$ & $85.8 \%$ & $83.2 \%$ & $84.4 \%$ & $83.1 \%$ & $87.5 \%$ \\
Production line 8 & $88.1 \%$ & $90.1 \%$ & $85.6 \%$ & $91.1 \%$ & $93.6 \%$ & $92.6 \%$ & $94.6 \%$ & $98.3 \%$ \\
Production line 9 & $86.9 \%$ & $93.6 \%$ & $90.8 \%$ & $90.2 \%$ & $88.5 \%$ & $84.0 \%$ & $90.5 \%$ & $96.7 \%$ \\
\hline OVERALL & $\mathbf{8 7 . 9 \%}$ & $\mathbf{8 7 . 4 \%}$ & $\mathbf{8 4 . 3 \%}$ & $\mathbf{8 4 . 1 \%}$ & $\mathbf{8 0 . 6 \%}$ & $\mathbf{8 4 . 5 \%}$ & $\mathbf{8 7 . 8 \%}$ & $\mathbf{9 2 . 3 \%}$ \\
\hline
\end{tabular}




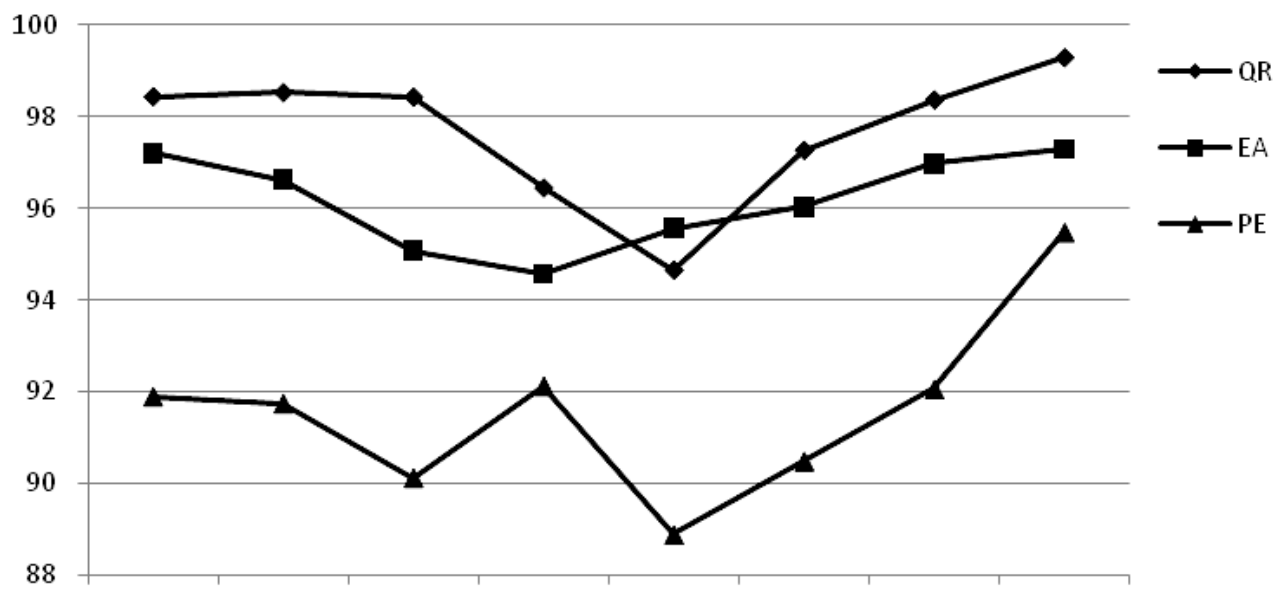

Q1/2011 Q.2/2011 Q3/2011 Q4/2011 Q1/2012 Q.2/2012 Q3/2012 Q4/2012

Legend: EA - Equipment Availability; PE - Performance Efficiency; QR - Quality Rate

Figure 1: Overview of of the three indicators used for calculating OEE during 24 months

tions. It is important to highlight that on some production lines up to 20 different products are produced so it took several months in order to record all changeover combinations. After the first year, time for changeovers has been determined and reset every three months. Table 4 shows SMED results for the second year of the project. Negative results show that more time was needed for changeovers than planned. This is in direct relation to problems that occurred on the lines and downtime that occurred from various failures. On the other side, on lines that didn't have problems positive results show big opportunities for decreasing time.
Latest fine-tuning in 2012 decreased SMED time for $7.6 \%$ or 3473 minutes.

\subsection{Problem solving sessions}

Problem solving sessions started in the 10th month of the project as an initiative of the Quality Assurance Department. As an input for problem solving sessions, initial training of the middle management from various sectors (production, quality, maintenance, design $\&$ development) in order to

Table 4: Quarterly analysis of changeovers in the second year

\begin{tabular}{lcccc}
\hline & \multicolumn{4}{c}{ Changeover improvement rate } \\
& Q1 / 2012 & Q2 / 2012 & Q3 / 2012 & Q4 / 2012 \\
\hline Production line 1 & $8.7 \%$ & $3.5 \%$ & $8.9 \%$ & $1.9 \%$ \\
Production line 2 & $0.1 \%$ & $-13.3 \%$ & $4.1 \%$ & $-38.3 \%$ \\
Production line 3 & $29.8 \%$ & $-3.6 \%$ & $8.2 \%$ & $26.7 \%$ \\
Production line 4 & $-20.0 \%$ & $0.0 \%$ & $0.0 \%$ & $40.0 \%$ \\
Production line 5 & $39.7 \%$ & $19.0 \%$ & $44.9 \%$ & $41.4 \%$ \\
Production line 6 & $5.3 \%$ & $7.4 \%$ & $-32.9 \%$ & $-2.8 \%$ \\
Production line 7 & $-12.5 \%$ & $-15.9 \%$ & $-17.3 \%$ & $-10.6 \%$ \\
Production line 8 & $-17.4 \%$ & $-14.2 \%$ & $-48.7 \%$ & $6.1 \%$ \\
Production line 9 & $-6.9 \%$ & $-10.8 \%$ & $-19.4 \%$ & $-1.8 \%$ \\
\hline Minutes of decreased time & $\mathbf{1 9 5 0}$ & $\mathbf{1 3 3}$ & $\mathbf{5 2 5}$ & $\mathbf{8 6 5}$ \\
\hline
\end{tabular}

Positive results show rate of improving (decreasing) total changeover time; negative results show higher results than planned.

Q1 / 2012 (months 13 - 15), Q2 / 2012 (months 16 - 18), Q3 / 2012 (months 19-21), Q4 / 2012 (months 22 - 24) 
achieve multidisciplinary team. Training included problem solving techniques, Ishikawa diagrams, root cause analysis and $5 \mathrm{~W}$ methodology. Brainstorming was promoted giving all participants equal possibility to identify root cause(s) and suggest solutions. A total of 19 problem solving sessions with an average of two meeting per session were initiated with $58 \%$ of solving effectiveness, and the remaining converted to on-going projects. Problems that were being solved indicate four categories - equipment efficiency, product quality, production process capability and organization of work. In average, eight participants took active roles per every session.

\section{$4.55 \mathrm{~S}$}

In months $4-6$ of the first year, training for implementing $5 \mathrm{~S}$ tools in maintenance has been performed. Along with the training a checklist has been created to evaluate implementation of all five steps in $5 \mathrm{~S}$ giving each "S" 5 question weighing 20 points (4 points each). In total 100 points was the maximal value for full implementation. First set of question for "sort" outlined sorting of equipment, spare parts, tools, aspects of visual control and existence of obsolete inventory (with red tags) including written standards and documents. Second set of questions for "set in order" highlighted existence of location indicators for shelves and storage areas, item indicators and various signboards, quantity indicators, demarcation and inventory areas and arrangement of jigs and tools. "Shine" set of questions emphasized cleanliness of floors, machines, work surfaces, cleaning responsibilities and habitual cleanliness. Fourth set of questions for "standardize" highlighted use of $5 \mathrm{~S}$ documents and visual standards of the maintenance area as well as improvement ideas and plans. Set of "sustain" questions, highlighted overall evaluation in light of awareness of workers, storage of all elements (tools, equipment, and parts), area control and use of visual control tables. Starting from the $6^{\text {th }}$ month, $5 \mathrm{~S}$ has been evaluated on a quarterly basis in 5 sectors - 'Fitters workshops', 'Mechanical workshops', 'Handy storage', 'Storage of spare parts' and 'Offices' (Table 5). Overall, in maintenance $5 \mathrm{~S}$ improved from 29.9 to 60.3 .

The main two constraints were to use "red tags" and identify unnecessary inventory as well as to sustain $5 \mathrm{~S}$ practice. Mainly workers complained that they have their own working habits for many years and that sustain of $5 \mathrm{~S}$ is time consuming.

\subsection{Total productive maintenance}

Total productive maintenance (TPM) was another tool used. Within the project, three main pillars have been identified: autonomous maintenance, planned maintenance and quality maintenance. Within planned maintenance, calculation of maintenance indicators has been initiated during the $16^{\text {th }}$ month. As the key indicators mean time between failure (MTBF) has been calculated for production line "11" for the period 2006 - 2011 in order to evaluate this indicator in light of existing practice. MTBF has been calculated for all components on the production line, as well as for the entire line as an entity. At the end of 24 months MTBF has been calculated for nine production lines and results are presented in Table 6.

As a result of implementing TPM, new and developed TMP work instructions have been created in order to avoid technological failures that can be prevented. On five technological lines with developed work instructions, MTBF of components improved for $36 \%$.

\subsection{Development of continual improvement sector}

After 12 months, a new organizational function has been established - the continual improvement (CI) manager with the responsibility to promote cultural change necessary to implement lean manufacturing. Its main objective is to identify opportunities for continual improvement in

Table 5: Evaluation of 5S in various areas of maintenance department

\begin{tabular}{lcccccc}
\hline & $\begin{array}{c}\text { Fitters work- } \\
\text { shops }\end{array}$ & $\begin{array}{c}\text { Mechanical } \\
\text { workshops }\end{array}$ & Handy storage & $\begin{array}{c}\text { Storage of } \\
\text { spare parts }\end{array}$ & Offices & Overall score \\
\hline Q2 / 2011 & 29 & 26 & 38 & 36.5 & 20 & 29.9 \\
Q3 / 2011 & 37 & 36 & 33.5 & 44 & 26.5 & 35.4 \\
Q4 / 2011 & 28.5 & 42 & 38.5 & 50.5 & 37.5 & 39.4 \\
Q1 / 2012 & 38 & 40 & 43.6 & 65 & 48.1 & 46.94 \\
Q2 / 2012 & 48.6 & 50 & 52.5 & 70 & 58.8 & 55.98 \\
Q3 / 2012 & 48 & 55 & 53 & 69 & 65.3 & 58.06 \\
Q4 / 2012 & 56.5 & 54 & 53.3 & 70 & 67.7 & 60.3
\end{tabular}


Table 6: MTBF at the end of first and second year of the project

\begin{tabular}{lccc} 
& $\begin{array}{c}\text { Average MTBF } \\
\text { in 2011 [h] }\end{array}$ & $\begin{array}{c}\text { Average MTBF } \\
\text { in 2012 [h] }\end{array}$ & Improvement [\%] \\
\hline Production line 1 & 225.3 & 228.7 & $1.5 \%$ \\
Production line 2 & 114.8 & 155.0 & $35.0 \%$ \\
Production line 3 & 55.9 & 60.9 & $8.8 \%$ \\
Production line 4 & 319.8 & 312.9 & $-2.1 \%$ \\
Production line 5 & 50.6 & 82.0 & $61.9 \%$ \\
Production line 6 & 156.0 & 170.3 & $9.2 \%$ \\
Production line 7 & 55.1 & 59.5 & $7.9 \%$ \\
Production line 8 & 204.6 & 241.8 & $18.2 \%$ \\
Production line 9 & 66.3 & 70.9 & $6.9 \%$ \\
& & Average & $16.4 \%$
\end{tabular}

Positive results show improved MTBF (increased time compared to previous year); negative results show shortening in calculated MTBF

two directions. First is working with all employees through organizing internal trainings and presenting lean tools as well as organizing weekly workshops with production, quality assurance and maintenance. All employees have the possibility to initiate their own suggestions for improvement and CI manager is responsible to evaluate all suggestions and to organize and monitor their implementation. Second is calculating and evaluating production, quality and maintenance indicators and identifying areas for optimizing quality costs, resources and processes.

\section{Conclusion}

As a result of all activities, 20 in-house trainings and 2 'Kaizen' events including motivational training have been initiated with 54 documents being revised and improved in order to contribute to more efficient processes.

The main challenge in this project was gaining commitment from employees due to the fact that some employees understood the entire project as additional control, more work for them and threat of losing their jobs. Middle and top management put much effort in promoting the entire idea and explaining the necessity for workers to participate and give their contribution. Unlike implementing management standards where implementation process is usually a 'top - down' method, in lean manufacturing, the company implemented 'down-up' method enabling workers fully participate and giving them the possibility to present their improvement ideas.

Limitations of the research stem from the use of results from one company so the results should not be generalized. Given the great technological and other differences within various food industries, more research is necessary to determine if similar results would be derived from different companies across various other food industries.

\section{References}

Alsaleh, N. A. (2007). Application of quality tools by the Saudi food industry. The TQM Magazine, 19(2), 150-161, http:// dx.doi.org/10.1108/09544780710729999

Alukal G., \& Manos A. (2006). Lean Kaizen - A Simplified Approach to Process Improvements. Milwaukee, Wisconsin: ASQ Quality Press.

Arauz, R., \& Suzuki, H. (2004). ISO 9000 performance in Japanese industries. Total Quality Management \& Business Excellence, 15(1), 3-33, http://dx.doi.org/10.1080/14783360320001490 72

Beheshti, H. M., \& Lollar, J. G. (2003). An empirical study of USSMEs using TQM. Total Quality Management \& Business Excellence, 14(8), 839-847, http://dx.doi. org/10.1080/1478336032000090798

Cagliano, R., Caniato, F., \& Spina, G. Lean, Agile and traditional supply: how do they impact manufacturing performance? Journal of Purchasing and Supply Management, 10(4-5), 151-164, http://dx.doi.org/10.1016/j.pursup.2004.11.001

Chan, F. T. S., Lau, H. C. W., Ip, R. W. L., Chan, H. K., \& Kong, S. (2005). Implementation of total productive maintenance: A case study. International Journal of Production Economics, 95(1), 71-94, http://dx.doi.org/10.1016/j.jpe.2003.10.021

Eroglu, C., \& Hofer, C. (2011). Lean, leaner, too lean? The inventory-performance link revisited. Journal of Operations Management, 29(4), 356-369, http://dx.doi.org/10.1016/j. jom.2010.05.002

Feld M. W. (2001). Lean manufacturing : tools, techniques, and how to use them. Boca Raton, Florida, USA: The St. Lucie Press/APICS Series on Resource Management.

Fotopoulos, C. V., Psomas, E. L., \& Vouzas, F. K. (2010). Investigating total quality management practice's inter-rela- 
tionships in ISO 9001:2000 certified organisations. Total Quality Management \& Business Excellence, 21(5), 503-515, http://dx.doi.org/10.1080/14783363.2010.481512

Higgins R. L., \& Wikoff J. D. (2008). Maintenance Engineering Handbook (7th ed.). USA: McGraw Hill.

Holweg, M. (2007). The genealogy of lean production. Journal of Operations Management, 25(2), 420-437, http://dx.doi. org/10.1016/j.jom.2006.04.001

Lagrosen, Y., \& Lagrosen, S. (2005). The effects of quality management - a survey of Swedish quality professionals. [Article]. International Journal of Operations \& Production Management, 25(9-10), 940-952, http://dx.doi. org/10.1108/01443570510619464

Losonci, D., Demeter, K., \& Jenei, I. (2011). Factors influencing employee perceptions in lean transformations. International Journal of Production Economics, 131(1), 30-43, http:// dx.doi.org/10.1016/j.ijpe.2010.12.022

Melton, T. (2005). The Benefits of Lean Manufacturing: What Lean Thinking has to Offer the Process Industries. Chemical Engineering Research and Design, 83(6), 662-673, http:// dx.doi.org/10.1205/cherd.04351

Monden Y. (1983). A Practical Approach to Production Management. Norcross, GA: Industrial Engineers and Management Press.

Ohno T. (1998). Toyota Production System: Beyond Large-Scale Production. Portland, Oregon: Productivity Press.

Panizzolo, R. (1998). Applying the lessons learned from 27 lean manufacturers.: The relevance of relationships management. International Journal of Production Economics, 55(3), 223240, http://dx.doi.org/10.1016/S0925-5273(98)00066-8

Psomas, E. L., \& Fotopoulos, C. V. (2010). Total quality management practices and results in food companies. International Journal of Productivity and Performance Management, 59(7), 668-687, http://dx.doi.org/10.1108/17410401011075657

Rooney S., \& Rooney J. (2005). Lean Glossary. Quality Progres, 38, 41-7.

Rubio, S., \& Corominas, A. (2008). Optimal manufacturingremanufacturing policies in a lean production environment. Computers \& Industrial Engineering, 55(1), 234-242, http:// dx.doi.org/10.1016/j.cie.2007.12.009

Schonberger, R. J. (2007). Japanese production management: An evolution--With mixed success. Journal of Operations Management, 25(2), 403-419, http://dx.doi.org/10.1016/j. jom.2006.04.003

Shah, R., \& Ward, P. T. (2003). Lean manufacturing: context, practice bundles, and performance. Journal of Operations Management, 21(2), 129-149, http://dx.doi.org/10.1016/ S0272-6963(02)00108-0

Shah, R., \& Ward, P. T. (2007). Defining and developing measures of lean production. Journal of Operations Management, 25(4), 785-805, http://dx.doi.org/10.1016/j.jom.2007.01.019

Smith R., \& Hawkins B. (2004). Lean maintenance: reduce costs, improve quality, and increase market share. Oxford, UK: Elsevier Butterworth-Heinemann.

Sousa, S. D., Aspinwall, E., Sampaio, P. A., \& Rodrigues, A. G. (2005). Performance measures and quality tools in Portuguese small and medium enterprises: Survey results. Total Quality Management \& Business Excellence, 16(2), 277-307, http:// dx.doi.org/10.1080/14783360500054434

Van Der Spiegel, M., Luning, P. A., De Boer, W. J., Ziggers, G. W., \& Jongen, W. M. F. (2006). Measuring effectiveness of food quality management in the bakery sector. Total Quality Management \& Business Excellence, 17(6), 691-708, http:// dx.doi.org/10.1080/14783360600594248

Van der Spiegel, M., Luning, P. A., Ziggers, G. W., \& Jongen, W. M. F. (2003). Towards a conceptual model to measure effectiveness of food quality systems. Trends in Food Science \& Technology, 14(10), 424-431, http://dx.doi.org/10.1016/ S0924-2244(03)00058-X

Ilija Djekic is an assistant professor at the Department for Food Safety and Quality Management at the Faculty of Agriculture, University of Belgrade, Serbia. He teaches QMS in food industry, quality costs and improvement techniques at bachelor and master studies. In the academic field, he has more than 75 scientific and technical papers published in Serbia and abroad and three quality related books. Prior to joining the University, he worked as a QMS, EMS and FSMS lead auditor for US and UK certification bodies and has more than more than 500 second and third party audits - most of them in the food industry. He has more than 50 quality and/ or food safety consulting projects and worked as a tutor on more than 30 accredited courses for lead auditors. His work comprises food industry performance in the quality fields, focused on applied, field research. Areas of research: quality assurance and lean manufacturing in food industry.

Dragan Zivanovic is a Technical Director at the Concern Bambi-Banat JSC, since of 2008. He is responsible for organizing the Production Department, cc. 700 employees (2 biscuit plants, 2 chocolate plants, on 2 remote locations, Maintenance, Investments, Continuous Improvements, Industrial Performance and in 4 years period R\&D), achieving business goals and leading company cost reduction projects. Prior to promotion as Technical Director, he was working on several positions in Production Department (Process Technologist, Shift Manager, and Production Manager). He was the HACCP team leader in the period 2002-2007, implementing Hygiene Management and HACCP system in biscuit plants (certificated in 2002-first one in Serbia), chocolate plants and at that time mineral water and cold storage plants. He also was successfully leading most important company projects related to process optimization, change management, cost savings and technical part during merging process of chocolate and biscuit plants.

Sladjana Dragojlovic is a Quality Assurance Director at the Concern Bambi-Banat JSC, since of 2008. She is responsible for an effective implementation and constant improvement of Quality, Environmental and Food Safety Management system within the company. After graduating, as Graduate engineer for food technology - University of Belgrade, she started her career as Quality control , water treatment and syrup room supervisor at Coca Cola 
Hellenic Bottler Company (CCHBC), Belgrade, where she gained experience in quality standards and process and machine capability study. She also worked as FSMS lead auditor for TÜV SÜD, German certification body and has more than 100 second and third part audits in food industry. She successfully completed various trainings in the fields of HACCP, food safety management system, quality management, and laboratory quality assurance.

Radoslava Dragovic is a Continuous Improvement Manager at the Concern Bambi-Banat JSC, since December 2011. She graduated from Faculty of Technology and Metallurgy, University of Belgrade, Department of Biochemical Engineering and Biotechnology. Being part of scholarship program during her studies, she joined Bambi-Banat's team in 2007. After trainee program, she was assigned to $R \& D$, as assistant to product manager and project leader. She anticipated in several courses, seminars, programs: REFA-Seminar - Process Data Management, AAK Academy - Filing Fats Seminar for the Chocolate and Confectionery Industry, Zagreb School of Economics and Management - Product Design, Development and Management by Carlos Rodriguez, Faculty of Agriculture, University of Belgrade - General guidelines for the selection, training and verification of assessors, according to standards ISO 8585-1:1993 and SRPS ISO 8586-1: 2002, Etol d.d. Slovenia - Sensory Evaluation Workshop, Chamber of Commerce Belgrade - Successful Models of Measuring Performance of Employees. 